\title{
FISH PRODUCTION IN RIVERS UNDER HUMAN IMPACT
}

Tadeusz PENCZAK* and Richard H.K. MANN**

* Institute of Environmental Biology, University of Lodz 90-237 LODZ ul. Banacha $12 / 16$, POLAND

* Freshwater Biological Association, River Laboratory, East Stoke, Wareham, Dorset BH20 6BB, England.

Key words: Fishes. Production. River. Human impact.

\section{SUMMARY}

The measurement of fish production is potentially a useful tool in fishery management. Not only can it be used to asses the impact of environmental change on the well-being of a population, but it can lead to an estimate of the optimum harvest (or yield) for a particular fishery. But the successful application of production information depends greatly on the accuracy of the component data, especially population density. Gross errors in these quantitative estimates can result in ill-advised management regimes.

Relatively few of the papers examined in this review deal directly with the effects of habitat change, and those that do are confined largely to studies of salmonid-dominated fish communities. Most other invertigations may be classed as fundamental research projectsdesigned to advance our knowledge of fish population dynamics, and to provide a firm ecological basis for future fishery management.

Tha mechanisms controlling the levels of fish produc tion in rivers are still poorly understood (MAHON,BALON, 1985) Abiotic factors, especially floods, appear to determine population densities in many head-water habitats (CRISP et al., 1974, 1975; WATERS, 1983; PENCZAK, MOLINSKI, 1984). But the potential maximum production in such waters may be under biotic control (MAHON, BALON, 1985; ZALEWSKI, NAIMAN, 1985), chiefly through the levels of autochthonous and allochthonous food resources, which regulate growth rates (STATZNER, HIGLER, 1985); though even these variables may be under abiotic influence.(WATERS, 1983; ZALEWSKI, NAIMAN, 1985). Hence the density-dependent regulating mechanisms for salmoids, often apparent in more productive waters, are rerely brought into play because population densities are not sufficiently high. Where they operate in more stable environments, then cover for fish (plants, stones) can play a major role in setting the levels of population density.

Fish production data (in the Ivlev sense) have much potential in fishery management, especially in assessing the impact of environmental perturbations or in determining optimum fish harvests. But the component parameters require accura

IV CONGRESO ESPAÑOL DE LIMNOLOGIA

Actas : $25-37$ 
te estimation in order to predict the outcome of a particular management regime with any confidence. Errors in riverine studies can arise from the variability of habitats along the river continuum (STATZNER, HIGLER, 1985; ZALEWSKI, NAIMAN, 1985) unless sampling sites are chosen with sufficient care to avoid fish species composition or age-structures to be misrepresented in the samples.

Productivity levels are under both biotic and abiotic influence, with the latter being of prime importance in many upland waters. Biotic variables (cover, food, predation) have more influence in stable environments, although physical parameters, especially water temperature, can still play a major role in determining the characteristics of local fish populations.

Salmonid studies dominate the literature; but as yet we know little about the dynamics of non-salmonid populations. We would encourage more studies on the latter, particularly of the 0 group fish.

\section{INTROQDUCTION}

To begin the title of this paper it is necessary to explain that there are no restrains in its contents. We would like to underline that pristine rivers are almost nonexistent phenomenon nowadays (HORWITZ, 1978; SEDELL, LUCHESSA, 1982; STATZNER, HIGLER, 1985). We suppose that main source of limitations so as to explain the relationships between production values and abiotic and biotic factors are connected with unknown precise human impact extended to the investigated river.

The International Biological Programme provided a useful stimulus to production studies at all trophic levels and led, directly of indirectly, to several review articles pertaining to fish (CHAPMAN, 1967, 1978; WATERS, 1977; MORGAN et al., 1980; NEVES, 1981). Despite all this activity, it was noted by MORGAN et al. (1980) that factual information on basic parameters such as mean biomass and production was sparse. The above reviews embrace both lacustrine and riverine studies, but in our paper we concentrate on the problems associated with flowing-waters. In particular we examine the constraints that such habitats impose upon the estimation of fish production, and we discuss the factors which determine productivity levels.

\section{DEFINITION}

Despite the efforts of many writers (e.g. CHAPMAN, 1967; WATERS, 1977) there is still confusion in the literature over the use the term "produc tion". In this paperwe use production in the IVLEV (1945) sense: Production is the total quantity of tissue elaborated by a fish population during a stated period of time, even though not all of it may survive to the end of that time.

As production as a synthesis of population biomass, recruitment and the instantaneous rates of growth and mortality, it is especially responsive to the welfare of the population and to the effects of environmental change. However, production does not indicate fully the importance of a particular group of animals (e.g. cohort, population) in terms of energy turnover, although such information may be acquired vis production estimates (ALLEN, 1951; 
TABLE I.- Range of production ( $P$ ) estimates and turnover ratio ( $P / B$ ) for nonsalmonid fishes in North American rivers.

\begin{tabular}{|c|c|c|c|c|}
\hline SPECIES & $P\left(g m^{-2} y r^{-1}\right)$ & $\begin{array}{c}\text { No. of } \\
\text { estimates }\end{array}$ & $\mathrm{P} / \mathrm{B}$ & $\begin{array}{c}\text { No. of } \\
\text { estimates }\end{array}$ \\
\hline Ambloplites rupestris & $0.03-0.24$ & 2 & 1.13 & 1 \\
\hline Campostoma anomalum & $0.89-1.36$ & 2 & & \\
\hline Catastomus commersoni & $0.14-4.20$ & 2 & $2.03-3.92$ & 2 \\
\hline Clinostomus funduloides & 0.07 & 1 & & \\
\hline Cottus bairdi & 0.82 & 1 & & \\
\hline C. carolinae & 4.25 & 1 & & \\
\hline C. cognatus & 5.94 & 1 & 1.20 & 1 \\
\hline Cyprinodon nevadensis & $155.40^{*}$ & 1 & 5.00 & 1 \\
\hline Etheostoma caeruleum & $0.06-0.63$ & 3 & 1.33 & 1 \\
\hline ․ flavellare & $0.02-1.65$ & 6 & $1.35-2.36$ & 1 \\
\hline E. nigrum & $0.06-0.36$ & 3 & 3.01 & 1 \\
\hline $\mathbb{E}$, sagitta & $0.06-0.42$ & 2 & & \\
\hline E. spectabile & 2.65 & 1 & & \\
\hline Ericymba buccata & 0.16 & 1 & & \\
\hline Hypentelium nigricans & $0.64-5.48$ & 2 & $1.30-1.97$ & 2 \\
\hline Micropterus dolomieui & $0.01-0.05$ & 2 & 7.53 & 1 \\
\hline Moxostoma rhothoecum & 0.54 & 1 & & \\
\hline Nocomis leptocephalus & 0.11 & 1 & & \\
\hline Notropis chrysocephalus & 0.17 & 1 & & \\
\hline N. cornutus & $0.30-1.99$ & 2 & $2.07-3.10$ & 2 \\
\hline Pimephales notatus & $0.38-1.36$ & 3 & $2.79-3.10$ & 3 \\
\hline Prospium williamsoni & 5.31 & 1 & & \\
\hline Rhinichthys atratulus & $0.32-0.36$ & 3 & $2.39-2.50$ & 2 \\
\hline R. cataractae & $0.10-0.86$ & 3 & $2.22-2.92$ & 2 \\
\hline Semotitlus atromaculatus & $0.81-9.26$ & 5 & $1.05-2.48$ & 5 \\
\hline Mean $( \pm 95 \%$ conf. limits $)$ & $1.56( \pm 0.85)$ & & $3.01( \pm 1.25)$ & \\
\hline
\end{tabular}

data from: GOODHIGGHT, BJORNN, 1971; LOTRICH, 1973; SMALL, 1975; PETROVSKY, WATERS, NAIMAN, 1976; MAHON et al., 1979; HALYK, BALON, 1983; NEVES, PARDUE; 1983; PENCZAK, MAHON, BALON, 1984).

* not included in the mean value.

WARREN et al., 1964; MAN, 1982, 1983).

Production, as defined above, should not be confused with "yield", although the two words are sometimes treated as synonyms. In fishery terms, yield is that part of the annual production of a population that is cropped by man, or moves from one habitat to another (as in the migration of Salmo salar smolts to the sea). Thus yield is dependent upon the level of production and, in a fishery, on the degree of fishing effort. Conversly, a high fishery yield (hence a high fishing mortality) may affect subsequent production by reducing the number of larger, older fish, as occurred with Barbus callensis in an Algerian river (PENCZAK, MOLINSKI, 1984).

Note that production is rate; it is expressed as weight (or energy) per unit area per unit time.

Presentation of methods how to measure of production and its components (density, mortality, fecundity, instantaneous growth rate, body length 
TABLE II.- Range of production ( $P$ ) estimates and turnover ratio ( $P / B$ ) for salmonid fishes in rivers.

\begin{tabular}{lcccc}
\hline \multicolumn{1}{c}{ SPECIES } & $\mathrm{P}\left(\mathrm{g} \mathrm{m}^{-2} \mathrm{yr}^{-1}\right)$ & $\begin{array}{c}\text { No. of } \\
\text { estimates }\end{array}$ & $\mathrm{P} / \mathrm{B}$ & $\begin{array}{c}\text { No. of } \\
\text { estimates }\end{array}$ \\
\hline Salmo clarki & $3.50-4.90$ & 3 & $0.87-1.06$ & 3 \\
S. gairdneri & $1.30-13.20$ & 4 & 1.49 & 1 \\
S. salar & $0.22-11.00$ & 16 & 1.41 & 2 \\
S. trutta & $0.11-54.70$ & 53 & $0.48-2.70$ & 37 \\
S. alpinus & $0.01-2.22$ & 8 & & 9 \\
S. fontinalis & $0.64-30.00$ & 11 & $0.71-2.54$ & 9 \\
Oncorhynchus kisutsch & 8.00 & 3 & & \\
O. tschwytscha & $0.60-2.51$ & 2 & & $1.57( \pm 0.31)$ \\
Means ( $\pm 95 \%$ conf. limits) & $9.65( \pm 3.05)$ & & \\
\hline
\end{tabular}

data from: ALLEN, 1951; HORTON, 1961; HORTON et al., 1968; CHAPMAN, 1965, 1966 LOWRY, 1966; COOPER, SCHERER, 1967; LIBOSVARSKY, 1968, 1971; HUNT, 1969, 1974; Le CREN, 1969; ELWOOD, WATERS, 1969; LUSK, ZDAZILEK, 1969; EGGLISHAW, 1970; LIBOSVARSKY, LUSK, 1970; HOPKINS, 1971; MAN, 1971; POWER, 1973; ALAKSANDER, MaCCRIMON, 1974; CRISP et al., 1974, 1975; HANSON, WATERS, 1974; MORTENSEN, 1977, 1982; EGGLISHOW, SHACKLEY, 1977; CRISP, CUBBY, 1978; MILNER, et al., 1978; O'CONNOR, POWER, 1976; WATERS, 1982, 1983; WITWORTH, STRANGE, 1983; LOBON-CERVIA, PENCZAK, 1984; PENCZAK et al., 1985; LOBON-CERVIA et al., 1986.

and body weight at time of annulus formation and so on) is not indispensable for the limnologists and ecologists. We considerer that we should be mainly concentrating on factors wich are limiting our investigations in rivers.

We belive that it is not difficult to investigate the fish production value at site in small, lowland, aluvial rivers. in such rivers with limited hiding places, reduced to small clamps of macrophytes, we can conduct almost total catch (PENCZAK, 1981). But accuracy of a sampling and its credibility is inversly correlated with river size. Not everyone remembers about the inexorable pressure of the truth included in this statement and makes attempt at assessing fish stock in bigger and bigger rivers. Such obstinate enthusiasts may sometime, however, contribute to the development of knowledge.

In rivers whose water levels fluctuate widely there is a difficulty in assessing stream area. LOTRICH (1973) suggested that stream length may be more useful than area as the basis for appraising or comparing the dynamics of intermittent streams. However, he used minimum stream area on which to base his production estimates, as have other involved with streams with a variable discharge (CRISP, et al.,. 1974, 1975; PENCZAK, MOLINSKY, 1984). The latter authors observed a ten-fold difference in the production level of fish in a seasonal river in north Algeria, depending on whether minimum or maximum stream area was used in the computation.

\section{REVIEW OF THE LITERATURE}

The range of production estimates and turnover ratios ( $P / B$ ) for salmonid fishes world-wide and for non salmonids in Europe and North America are shown in Tables I-III. Few data were found for rivers outside Europe and North 
TABLE III.- Range of production ( $P$ ) estimates and turnover ratio ( $P / B$ ) for non-salmonids fishes in European rivers.

\begin{tabular}{|c|c|c|c|c|}
\hline SPECIES & $P\left(g m^{-2} y r^{-1}\right)$ & $\begin{array}{l}\text { No. of } \\
\text { estimates }\end{array}$ & $\mathrm{P} / \mathrm{B}$ & $\begin{array}{l}\text { No. of } \\
\text { estimates }\end{array}$ \\
\hline Abramis brama & 0.15 & 1 & & \\
\hline Alburnus alburnus & 52.80 & 1 & 1.62 & 1 \\
\hline Alburnoides b. strimonicus & $0.03-0.12$ & 3 & 1.23 & 3 \\
\hline Anguilla anguilla & $0.09-9.30$ & 5 & $0.57-1.73$ & 3 \\
\hline Aspius aspius & 0.15 & 1 & 0.49 & 1 \\
\hline Barbus barbus & $0.60-0.43$ & 2 & 1.87 & 1 \\
\hline B. cyclolepis & $0.50-5.61$ & 5 & 1.10 & 5 \\
\hline B. b. bocagei & $0.23-17.50$ & 5 & $0.30-1.44$ & 5 \\
\hline Blicca bjoerkna & 0.01 & 1 & & \\
\hline Chondrostoma nasus & $0.01-0.95$ & 2 & 0.20 & 1 \\
\hline C. polylepis & $1.59-10.01$ & 6 & $0.56-1.72$ & 6 \\
\hline Cobitis paludicola & 0.14 & 1 & 1.98 & 1 \\
\hline Cottus gobio & $0.40-43.10$ & 12 & $1.33-3.19$ & 3 \\
\hline Exox Iucius & $0.15-0.52$ & 5 & $0.67-1.16$ & 4 \\
\hline Gasterosteus aculeatus & $0.10-42.30$ & 7 & $0.90-3.70$ & 5 \\
\hline Gobio gobio & $0.03-11.70$ & 11 & $1.00-2.86$ & 11 \\
\hline Leucaspius delineatus & 0.09 & 1 & 2.25 & 1 \\
\hline Leuciscus cephalus & $0.01-9.40$ & 12 & $0.28-2.03$ & 12 \\
\hline L. leuciscus & $0.23-2.60$ & 3 & $0.37-1.75$ & 3 \\
\hline Lota lota & 0.01 & 1 & & - \\
\hline Noemacheilus barbatulus & $0.10-17.35$ & 6 & $0.21-1.90$ & 2 \\
\hline N. bureschi & $0.01-2.31$ & 3 & 1.32 & 3 \\
\hline Perca fluviatilis & $0.01-2.03$ & 3 & 0.30 & 1 \\
\hline Phoxinus phoxinus & $0.01-3.90$ & 9 & $1.90-2.00$ & 9 \\
\hline Pungitius pungitius & 1.80 & 1 & 0.61 & 1 \\
\hline Rutilus rutilus & $0.20-17.80$ & 4 & $0.32-1.14$ & 3 \\
\hline R. arcasii & $0.03-1.55$ & 5 & $1.71-2.30$ & 5 \\
\hline Silurus glanis & 0.02 & 1 & 0.35 & 1 \\
\hline Stizostedion lucioperca & 0.09 & 1 & 0.66 & 1 \\
\hline Mean ( $\pm 95 \%$ conf. limits) & $5.89 \pm 2.86$ & & $1.32 \pm 0.42$ & \\
\hline
\end{tabular}

data from': BACKIEL, 1970, 1971; MATHEWS, 1970,1970; Le CREN, 1962; CRISP, et al., 1974, 1975, 1984; LIND, KAUKORANT, 1975, MANN, 1971,1980; PENCZAK et al., 1976,1982, PHILIPPART, 1977, 1981; RAMUSSEN, THERKILDSEN, 1979; PENCZAK, 1981; PENCZAK et al., 1985; KICKLEY, BAILEY, 1982; LOBON-CERVIA, PENCZAK, 1984 MANN, PENCZAK, 1984; PENCZAK, MOLINSKI, 1984; LOBON-CERVIA et al., 1986; $0^{\prime H A-}$ RA, PENCZAK, 1987.

America, notable exceptions being the studies by ALLEN (1951) and HOPKINS (1971) en New Zealand, and by BISHOP (1973) in small Malayan river in which estimates of 36 to $90 \mathrm{~g} \mathrm{~m}^{-2} \mathrm{yr}^{-1}$ for the whole fish community were obtained using the model described by HUET (1964), and by WATSON, BALON (1984) in rain forest stream of nothern Borneo where estimates of 26.1 to $261.5 \mathrm{~g} \mathrm{~m}^{-2} \mathrm{yr}^{-1}$. (mean: 76.7) for the all populations.

The highest estimate for single species is $155.4 \mathrm{~g} \mathrm{~m}^{-2} \mathrm{yr}^{-1}$ for the Armagosa pupfish, Cyprinodon nevadensis, a short-lived herbivore living in a warmwater spring $\left(28_{\left.-34^{\circ} \mathrm{C}\right)}\right.$ and subjet to year-round growth conditions (NAIMAN, 1976). Other high estimates are 54.7 for Salmo trutta (ALLEN, 1951), 52,8 for 


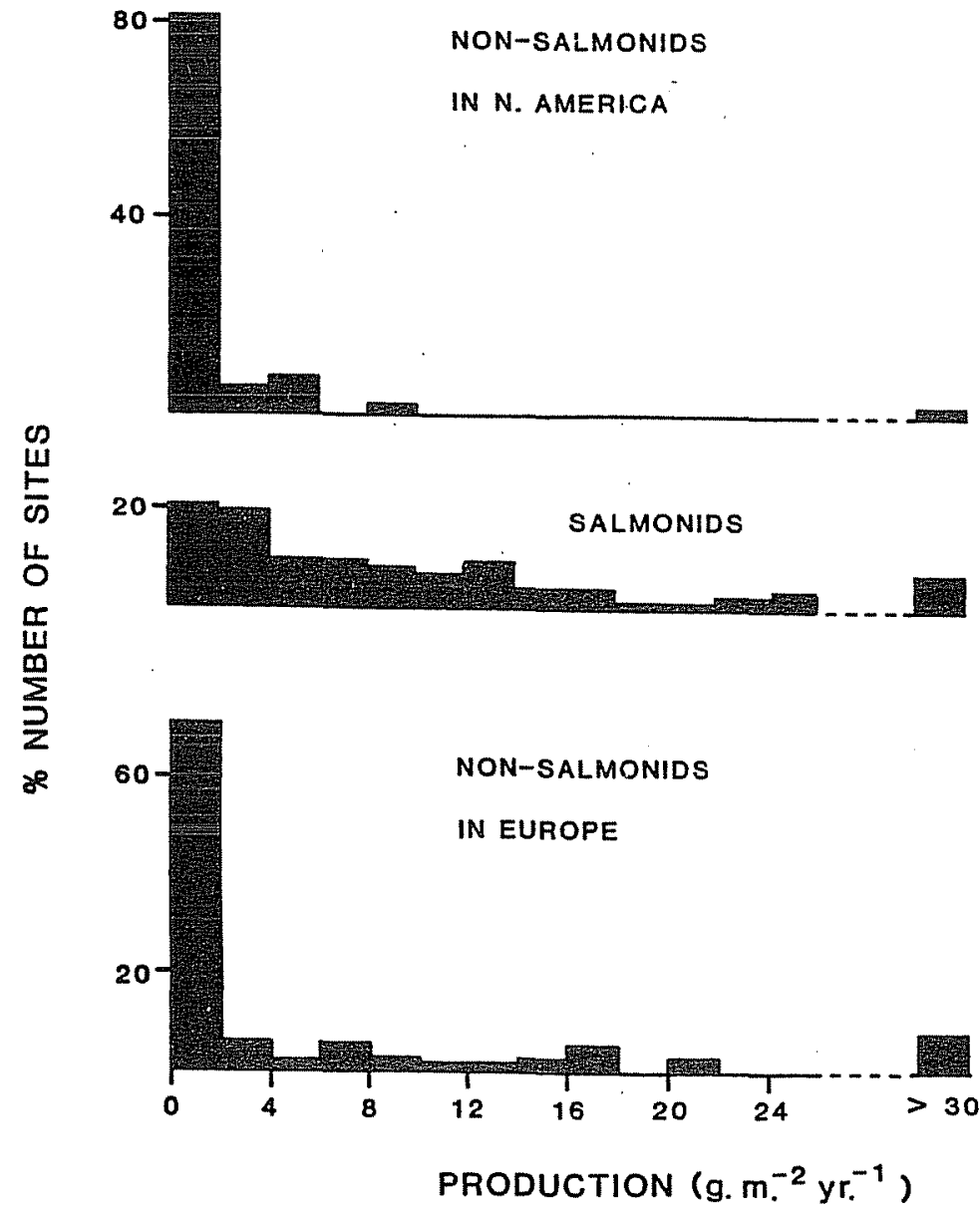

FIGURE 1

Frecuency-distribution (\%) of production estimates for non-salmonid fishes in North America $(N=48)$ and Europe $(N=118)$, and salmonid fishes world-wide $(N=100)$.

the small cyprinid Alburnus alburnus in the river Thames (MATHEwS, 1970, 1971) 43.1 for the sculpin, Cottus gobio in a small chalkstream in southern England (MANN, 1971), and 74.0 for. stone loach, Noemacheilus barbatulus in the upper course of the Utrata River, Poland (PENCZAK, 1981).

For stream salmonids, Le CREN (1969) suggested that there was an upper production limit of $12 \mathrm{~g} \mathrm{~m}^{-2} \mathrm{yr}^{-1}$. Subsequent studies have indicated the seiling to approximate $30 \mathrm{~g} \mathrm{~m}^{-2} \mathrm{yr}^{-1}$, and the frequency distribution (Fig. 1) shows that only four estimates equalled or oxceeded this value; viz. 54.7 (ALLEN, 1951), 46.2 (LOBON-CERVIA et al., 1986), and 33.1 (MORTENSEN, 1982) for S. trutta and 30.0 for Salvelinus fontinalis in Big Spring, Pennsylvania (COOPER, SCHERER, 1967).

More studies of salmonid production have been made than for any other group of fishes. ALLEN's (1951) high rate is often considered to be an overestimate, but COOPER, SCHERER (1967) point out that ALLEN's population 
estimates are similar to those for $S$. fontinalis in Big Spring, but the $S$. trutta grew very much faster. They argued that this faster growth is sufficient to explain the high trout production in the Horokiwi Stream.

The pronounced effect that local environmental conditions have on the level of fish production, particulary in relation to fish cover, was highlighted by CHAPMAN (1966). later, HUNT (1969) demostrated the effect experimentally; following habitat improvements in Lawrende Creek, Wisconsin he recor ded an increase fron 3.7 to $16.7 \mathrm{~g} \mathrm{~m}^{-2} \mathrm{yr}^{-1}$ in the production of $\mathrm{S}$. fontinalis. Natural variations. in relation to habitat structure were recorded also for S. trutta and C. gobio in a small stream in southern Engalnd (MANN, 1971,1933) Lower densities of both species were found in a heavily-shaded section than in a adjacent open containing many submerged macrophytes. No difference in growth rate were observed, but EGGLISHAW, SHACKLEY (1977) found the environmental factors influenced the population densities of $\mathrm{S}$. trutta and $\mathrm{S}$. salar in a scottish stream, and that growth rates were inversly proportional to population density. In many Norwegian rivers, the species S. trutta, S. salar and Salvelinus alpinus are segregated according to substrate type (POWER, 1973). Also, the presence of cover in the form of boulders and large stones greatly enhances the holding capacity of the rivers for fish, and hence influences the production level.

A benefical change as a result of man's activities was decribed by CRISP et al., (1984). The production of juvenile S. trutta in small moorland streams increased after the main river into which the llowed had been impounded to form a reservoir. An increase in the recruitment was related to an increased size of adults spawning in the tributaries (hence more eggs were laid) and to a deeper cutting of the redds by the larger adults (hence more eggs survived the effects of floods). The release of cold hypolimnial water from a new impoundment prevented the successful spawning of the previously abundant species Rhinichthys atratulus and Etheostoma flabellare (PENCZAK, et al:, 1984). These two species plus four less common ones were replaced by three new species in lite study area and, despite lower water temperatures, total annual production was tripled.

Geographic variation in the production of individual species, related to the basic productivity of the streams, has been recorded widely (COOPER, SCHERER, 1967; CRISP et al., 1974, 1975), and it is supported by the results of the enrichment of experimental streams with sucrose (WARREN, et al., 1964).

ALLEN (1969) suggested that natural selection, operating through the influence of environmental factors on individuals in two isolated populations, could result in genetic differentiation between the two groups. However a reciprocal transfer of $\mathrm{C}$. gobio between two very different habitats resulted in the transferred sculpins assuming the growth and reproductive characteristics of the local population (MANN et al., 1984). In this example, at least, the genotype appeared capable of a wide range of phenotipic expression, with the characteristics of a specific population being determinated by local conditions. Such plasticity of life-history tactics may underely the successful stablishment of many temperate species into a wide range of habitats (MANN, et al., 1984).

As it was mentioned in the chapter "Definition", the open-ended ratu re of rivers can pose problems in the study areas. By studying review work devoted to the assessment of fish stocks in rivers one can easily see that this difficult and time-consuming task has become a serious limitation in ecologi-cal theory. To minimize the obstacle, ichthyologists have examined and analysed many parameters influencing sampling and the accuracy of assessing density and standing crop, e.g. sampling time, sampling techniques, gear, behaviour 
of sampled animals, the use of environmental parameters, etc. (ZALEWSKY, 1986). However, the length of the river section used for sampling has not always been taken into account (PENCZAK, 1985). Consequently, the actual choice of site has not been a subject of investigation, and thus has been determined from arbitrary decisions. Only the homogenous structure of the section for sampling and the representation of the site for the investigated river section have been considered (PENCZAK, 1985); at the most it has been observed that when "the small species were numerous" it was sufficient to fish a shorter section of the river (WILLIAMS, HARCUP, 1974).

So far the importance of the choice of the river section, for the optimal density assessment, has been fully recognized and substantiated only for plant studies, inmobile invertebrates and large manmals.

In the case of large rivers, the problem of the choice of site is important because most of the qualitative and quantitative composition of ichthyofauna fluctuates commutatively along the whole course. The production of transistory fish can be estimated for the period they remain in the study area, provided that the frequency of sampling is adequate. But some data concerning fish movements, and more widespread sampling, are necessary if status of the whole (biological) populations is required. CRISP et al. (1974, 1975) tackled this problem by combaining an intensive study of a few, selected sites with a more general survey of many sites over whole of catchment. Although the sampling regime was compromise between logistics and scientific requeriments, combination of the two sets of data led to a realistic evaluation of fish production.

Because we gathered considerable amount of data on the turnover ratio (Table I-III) we would like to reveal a fact that no all investigators are using average biomass $(\bar{B})$ for calculation of production for no directly investigated species ("other species"). WATERS (1977) proposed the use of maximum biomass ( $B$ max.) instead of $B$, but we found no examples of its use in estimating fish production - possibly because $B$ max. is more difficult to determine from field data than is $\bar{B}$. ALLEN (1971) noted that both mean age and mean life-span are reciprocals of the $P / \bar{B}$ ratio if there is constant exponential mortality, a point also demeonstrated by LEVÊQUE (1978). Later, BANSE, MOSHER, (1980) examined the relationship between $\mathrm{P} / \overline{\mathrm{B}}$ and mean body weight at maturity; they found linear log:log relationships for several groups of animals including fish. However, more accurate data on $P / \bar{B}$ ratios are required for many fish species before any of these relationships can be used to determine produc tion levels accurately, although the information for salmonids is approaching this position.

\section{REFERENCES}

ALEXANDER,D.R., MacCRIMMON,H.R., 1971.- Production and movement of juvenile rainbow trout (Salmo gairdnieri) in a headwater of Bothwell's Creek, Georgian Bay, Canada. J. Fish. Res. Bd. Canada, 31 : 117-121

ALLEN, K.R., 1951.- The horokiwi Stream: a study of trout population. Fish Bull. N.Z., $10: 1-238$

ALLEN,K.R., 1969.- Limitations on production in salminod populations in streams. In Northcote, T.G I (ed.) Symposium on Salmon and Trout in streams : 3-18, MacMillan Lecture, Univ. Brithis Columbia.

ALLEN, K.R., 1971.- Relation between production and biomass. J. Fish. Res. Bd. Canada, 28 :1573-1581 
BACKIEL, T., 1970.- Production and consumpcion in the population of Aspius aspius (L.) of the Vistula River. Pol. Arch. Hydrobiol., $17 \overline{: 249-}$ 258

BACKIEL, T., 1971.- Production and food consumpcion of predatory fish in the Vistula River. J. Fish. Biol., 3 : 369-405

BANSE, K., MOSHER, S., 1980. Adult body mass and annual production/biomass relationships of field populations. Ecol. Monogr., 50 : 355-379

BISHOP,J.E., 1973. - Limnology of a small Malayan river, Sungai Gombak. W. Junk B.V. Publishers. The Hage.

CHAPMAN, D.W., 1965.- Net production of juvenile coho salmon in three Oregon streams. Trans. Am. Fish. Soc., $94: 40-52$

CHAPMAN, D.W., 1966.- Food and space as regulators of salmonid populations in streams. Am. Nat., $100: 345-357$

CHAPMAN, D.W., 1967.- Production in fish populations. In Gerking, S.D. (ed.), The biological Basis of Freshwater Fish Production : 3-29. Wiley. New York.

CHAPMAN, D.W., 1978.- Production in fish populations. In Gerking, S.D. (ed.), Ecology of Freshwater Fish Production : 5-25. Blackwell Sci. Publ. Oxford.

COOPER, E.L., SCHERER, R.C., 1967.- Annual production of brook trout (Salvelinus fontinalis) in fertile and infertile streams of Pennsylvania. Proc. Pa. Acad. Sc., 41 : 65-70

CRISP, D.T., CUBBY, P.R., 1978.- The populations of fish in tributaries of the River Eden on the Moor House National Nature Reserve, northern England. Hydrobiologia, 57 : 85-93

CRISP, D.T., MANN, R.H.K., CUBBY, P.R., 1984.- The effects of impoundment upon fish populations in afferent streams al Cow Green Reservoir. J.Appl. Ecol., $21: 739-756$

CRISP, D.T., MANN, R.H.K., MCCORMACK, J.C., 1974.- The populations of fish at Cow Green, Upper Teesdale, before impoundment. J. Appl. Ecol., 11 : 969-996

CRISP, D.T., MANN, R.H.K., MCCORMACK, J.C., 1975.- The populations of fish in the river tees system on the Moor House National Nature Reserve, Westmorland. J.Fish. Biolo., 7 : 573-593

EGGLISHAW, H.J., 1970.- Production of salmon and trout in a stream in Scotland J. Fish. Biol., 2 : 117-136

EGGLISHAW, H.J., SHACKLEY, P.e., 1977.- Growth, survival and production of juvenile salmon and trout in a Scottish stream, 1966-75. J. Fish. Biol., $11: 647-672$

ELWOOD, J.W., WATERS, T.F., 1969.- Effects of floods on food consumpcion and production rates of a stream brook trout population. Trans. Am. Fish Soc., $98: 253-262$

GOODNIGHT, V.H., BJORNN, T.C., 1971.- Fish production in two Idaho streams. Trans. Amer. Fish. Soc., $100: 769-780$

HASON, D.L., WATERS, T.F., 1974.- Recovery of standing crop and production rate of a brook trout population in a flood-damaged stream. Trans. Amer. Fish. Soc., 103 : 431-439 
HALYK, L.C., BALON, E.K., 1983.- Structure and ecological production of the fish taxocene of a small floodplain system. Can. J. Zool., $61: 2446$ $-2464$

HIKLEY, P. BAILEY, R.G., 1982.- Observations on the growth and production of chub Leuciscus cephalus and dace Leuciscus leuciscus in a small lowland river in southeast England. Freswat. Biol., 12 : 167-178

HOPKINS, C.L., 1971.- production of fish in two small streams in the north Island of New Zealand. N. Z. J. Mar. Frshw. Res., $5: 280-290$

HORTON, P.A., 1961.- The bionomics of brown trout in a Dartmoor stream. J. Anim. Ecol., 30 : 311-338

HORTON, P.A., BAILEY, R.G., WILSDON, S.I., 1968.- A comparative study of the bionomics of the salmonids of three Dartmoor stream. Arch. Hydrobiol $65: 187-204$

HORWITZ R.J., 1978.- Temporal variability patterns and the distributional patterns of stream fishes. Ecol. Monogr., 48:307-231

HUET, M., 1964.- The evaluation of fish productivity in fresh waters. Verh. Internat. Verein. Limnol., $15: 524-528$

HUNT, R.L., 1969.- Effects of habitat alteration on production, standing crop and yield of brook trout in Lawrence Creek, Wisconsin. In Northcote, T.G. (ed.) Symposium on Salmon and Trout in Stream : 281-312. Mac Millan Lecture, Univ. British Columbia

HUNT, R.L., 1974.- Annual production by brook trout in Lawrence Creek during eleven successive years. Wisc. Cons. Dept. Tech. Bull., 48 : 1-35

IVLEV, V.S., 1945.- The biological productivity of waters. Ups. Sovrem Biol., 19 : 198-220 (Engl. version 1966. J.Fish. Res. Bd. Canada, 23: 1727-1759).

LE CREN E. D. ., 1969.- Estimates of fish populations and production in small streams in England. In Northcote, T.G. (ed.) Symposium on Salmon and trout in Streams : 269-280, MacMillan Lecture. Univ. Bretish Columbia

LE CREN, D.D., 1972.- Fish production in freshwaters. Symp. Zool. Soc. Lond., $29: 115-133$

LEVÊQUE, C. 1978.- Estimation du rapport $P / B$ à partir de la longévité des espèces. Verh. Internat. Verein Limnol., $20: 2122-2166$

LIBOSVARSKY, J., 1968.- A study of brown trout population (Salmo trutta morpha fario L.) in Loucka Creek (Czechoslovakia). Acta Sci. Nat. Brno, 2:1-56

LIBOSVARSKY, J., 1971.- Umrtnost a produkce pstuha v pstruhovych tocich (Morta lity and production of brown trout in trout streams). Vertebr. Zpravy, 2 : 87 (engl. summ.)

LIBOSVARSKY, J., LUSK, S., 1970.- The bionomics and net production of brown trout (Salmo trutta morpha fario L.) in Loucka Creek, Czechoslovakia Ekol. pol., $18: 361-382$

LIND, E., KAUKORANTA, E., 1975.- The pike, Exos lucius L., in the estuary of the Oulujoki river. II Population. Ichth. Fenn. Bor., 3-4:41-66

LOBON-CERVIA, J., PENCZAK, T., 1984.- Fish production in the jarama River, Central Spain. Hol. Ecol., $7: 128-137$

LOBON-CERVIA, J., de SOSTOA; A., MONTANES, C., 1986.- Fish production and its relation with the community structure in a aquifer-fed stream of old-Castile (Spain). Pol. Arch. Hydrobiol., 33 
LOTRICH, V.A., 1973.- Growth, production and community composition of fishes inhabiting a first-, second- and third-order stream of eastern Kentucky. Ecol. Monogr., 43 : 377-397

LOWRY, G.R., 1966.- Production and food of the cutthroat trout in three Oregon coastal streams. J. Wildl. Mgmt., $30: 754-767$

LUSK, S., ZDRAZILEK, P., 1969,- Contribution to the bionomics and production of the brown trout (Salmo trutta $\mathrm{m}$. fario) in the Lusova Brook. Zool. listy, $18: 381-342$

MAHON, R., BALON, E.K., 1985.-Fish production in warmwater streams in Poland and Ontario. Can. J. Fish. Aquat. Sci., 42 :1211-1215

MAHON, R., BALON, E.K., NOAKES; D.L.G., 1979.- Distribution, community structu re and production of fishes in the upper Speed River, Ontario: $\bar{a}$ preimpoundment study. Env. Biol. Fish., 4 : 219-244

MANN, R.H.K., 1971.- The populations, growth and production of fish in four small streams in southern England. j. Anim. Ecol., 40 : 155-190

MANN; R.H.K., 1980.- The numbers and production of pike (Exos lucius) in two Dorset rivers. J. Anim. Ecol., 49 : 899-915

MAN R.H.K., 1983.- Fish production in English chalkstreams. Proc. 2nd Jornadas Ictiologia Ibérica, Barcelona (in print)

MANN, R.H.K., MILLS, C.A., CRISP, D.T., 1984.- Geographical variation in the life-history tactics of some species of freshwater fish. In wooton, R.J., (ed.) Fish Reproduction: Strategies and Tactics : 170-186, London, Academic Press.

MANN, R.H.K., PENCZAK, T., 1984.- The efficiency of a new electrofishing technique in determining fish numbers in a large river in Central Poland J. Fish. Biol., $24: 173-185$

MATHEWS, C.P., 1970.- Estimates of production with reference to general surveys. Oikos, $21: 129-133$

MATHEWS, C.P., 1971.- Contribution of young fish to total production in the River Thames near Reading. J. Fish. Biol., 3 : 157-180

MILNER, N.J., GEE, A.S., HEMSWORTH, R.J., 1978.- The production of brown trout Salmo trutta, in tributaries of the Upper Wye, Wales. J. Fish. Biol. $13: 599-612$

MORGAN, N.C., BACKIEL, T., BIETSCHKO, S., DUNCAN, A., HILLBRICHT-ILKOWSKA,A., KAJAK, Z., KITCHELL, J.F., LARSSON, P., LEVEQUE, C., NAUWERCK, A., SCHEMER, F., THORPE, J.E., 1980.- Secondary production. In. Le Cren, E.D., Lowe-McConnel1, R.H. (eds.) The Funtioning of Freshwaters Ecosystems : 247-340, Cambridge University Press.

MORTENSEN, E., 1977.- Fish production in small Danish streams. Folia Limnol. Scand., 17 : 21-26

MORTENSEN; E., 1982.- Production of trout, Salmo trutta, in a Danish stream Env. Biol. Fish., $7: 349-356$

NAIMAN, R.J., 1976.- Productivity of a herbivorous pupfish (Cyprinodon nevadensis) in a warm desert stream. J. Fish Biol., $9: \frac{\text { 125-137 }}{125}$

NEVES, R.J., 1981.- Fish production in warmwater streams. In Krumholz, L.A. (ed.) Warmwater Streams Symp., Am. Fish. Soc. : 356-363. Bethesda, Maryland, U.S.A.

NEVES, R.J., PARDUE; G.B., 1983.- Abundance and production of fishes in a small Appalachian stream. Trans. Am. Fish. Soc., 112 : 21-26 
O'CONNOR, J.F., POWER, G., 1976.- Production by brook trout (Salvelinus fontinaliis) in four streams in the Matamek watershed, Quebec. J. Fish. Res. Bd. Canada, 33 : 6-18

O'HARA, K., PENCZAK, T., 1987.- Production of the three-spined stickle-back, Gasterosteus aculeatus L.,' in the River Weaver, England. Freshwater Biology,

PENCZAK, T., 1981.- Ecological fish production in two small lowland rivers in poland. Oecologia (Berl.), $48: 107-111$

PENCZAK, T., 1985.- Influence of site area on the estimation of the density of fish populations in a small river. Aquaculture and Fish. Mgmt., $1: 273-285$

PENCZAK, T., JANKOV, J., DIKOV, Ts., ZALEWSKI, M., 1985.- Fish production in the Mesta River, Rila Mountain, Samokov, Bulgaria. Fish Res., 3 : 201-221

PENCZAK, T., MAHON, R., BALON, E.K., 1984.- The effect of an impoundment on the upstream and downs stream fish taxocenes (Speed River, Ontario, Canada). Arch. Hydrobiol., 99 : 200-207

PENCZAK, T., MOLINSKI, M., 1984.- Fish production in Oued Sebaou, a seasonal river in North Algeria. J. Fish Biol., 25 : 723-732

PENCZAK, T., SUSZYCKA, E., MOLINSKI, M., 1982.-production, consumption and energy transformation by fish populations in a small lowland river. Ecol. Pol., 30 : 111-137

PENCZAK, T., ZALEWSKI, M., MOLINSKI, M., 1976.-Production of pike, roach, and chub in a selected fragment of Pilica River (barbel region). Pol. Arc. Hydrobiol., 23 : 139-153

PETROVSKY, C.E., WATERS, T.F., 1975.- Annual production by the slimy sculpin population in a small Minnesota trout stream. Trans. Am. Fish. Soc., $104: 237-244$

PHILIPPART, J.C., 1977.- Contribution à l'étude de l'écosystème "Rivière de la zone à barbeau supèrieure" : densité, biomasse et production des populations de poisson de 1'-urthe. In: Duvigneaud, P., Kestemont,P. (eds.) Productivité biologique en Belgique : 551-567. Duculot, Gemloux

PHILIPPART, J.C., 1981.- Ecologie d'une population de vandoises, Leuciscus leuciscus (L.) dans la rivière Ourthe (bassin de la Meuse, Belgique) Annls. Limnol., $17: 41-62$

POWER, G., 1973.- Bstimates of age, growth, standing crop and production of salmonids in some north Norwegian rivers and streams. Rep. Inst. Freshwat. Res. Drottningholm, 53 : 78-111

RASMUSSEN, G., THERKILDSEN, B., 1979.- Food, growth and production of Anguilla anguilla L. in a small Danish stream. Rapp. P.-v. Reun. Cons. Int. Explor. Mer., 147 : 32-40

SEDELL, J.R., LUCHESSA, K.J., 1982.- Using the historical record as an aid to saiminid habitat enhancement. In Armantrout N.B. (ed.) Asquisition and utilization of aquatic habitats inventory information.: 210 -223. Western Division American Fisheries Society. Bethesda. MD.

SMALL, J.W., 1975.- Energy dynamics of benthic fishes in a small Kentucky stream. Ecologu, 56 : 827-840

STATZNER, B., HIGLER, B., 1985.- Questions and comments on the river continuum concept. Can. J. Fish. Aquat. Sci., 42 : 1038-1044 
WATSON, D.J., BALON, E.K., 1984.- Structure and production of fish communities in tropical rain forest streams of northern Borneo. Ca. J. Zool., 62 : $927-940$

WARREN, C.E., WALES, J.H., DAVIS, G.E., DOUDOROFF, P., 1964.- Trout production in a experimental stream enriched with sucrose. J. Wildl. Mgmt., 28 : 617-660

WATERS, T.F., 1977.- Secondary production in inland waters. Adv. Ecol. Res., $10: 91-164$

WATERS, T.F., 1982.- Annual production by stream Brook charr population and its principal invertebrate food. Env. Biol. Fish., 7 : 165-170

WATERS, T.F., 1983.- Replacement of brook trout by bronw trout over 15 years in a Minnesota stream: production and abundance. Trans. Am. Fish. Soc., 112 : 137-146

WHITHWORTH, W.E., STRANGE, R.J., 1983.- Growth and production of sympatric brook and rainbow trout in an Appalachian stream. Trans Am. Fis. Soc., 112 : 469-475

WILLIAMS, R., HARCUP, M.F., 1974.- The fish populations of an industrial river in South Wales. J. Fish. Biol., 6 : 395-414

ZALEWSKI, M., 1986.- Factors affecting the efficiency of electrofishing in rivers. Hydrobiology, 27 : 56-69

ZALEWSKI, M. Naiman, R.J., 1985.- The regulation of riverine fish communities by a continuum of abiotic-biotic factors. In. Alabaster, J.S., (ed.) Habitat modification and freshwater fisheries : 3-9. Butterworths, London. Boston. 